\title{
THE IMPACT OF THE IMPULSE BUYING DIMENSION AND CHERRY PICKING: AN EMPIRICAL STUDY (Consumers Case Study in a mall in Central Jakarta)
}

\author{
Endang Ruswanti \\ Universitas Esa Unggul Jakarta \\ (endangruswanti@gmail.com)
}

\begin{abstract}
The purpose of this research is to further test the contradictory research result. Mathai \& Haridas' findings (2014) stated that a discounted price did not influence impulse buying. Meanwhile Ruswanti, (2013) found that a discounted price tended to influence the consumers' spontaneous shopping. Data discovered by Nielsen (2007) stated that apparently $85 \%$ of Indonesian consumers tend to buy things on an impulse. This research was in the form of a survey, the sample being 197 people, of whom 96 respondents were female, and males the other 101. The respondents ages were between 17-50 years old, those with an income of 3 million rupiahs numbered 83 persons, 64 people had an income above 5 millions rupiahs, and 50 respondents had an income above 10 million rupiahs. The technical design was a purposive sampling; $70 \%$ of the consumers liked the discounted products, and bought something on the spur of the moment at least once. The regression analysis was with SPSS 19; the results show that the external, internal, situational environment, products'variety, and sociocultural effects significantly influenced the cherry picking. The respondents with an income of above 3-5 million preferred spontaneous shopping. This research gives a contribution to the development of the consumers' behavioral theory through impulse buying and cherry picking.
\end{abstract}

Keyword: impulsive buying dimension, cherry pick, consumer's behavioral, central Jakarta

\section{BACKGROUND}

The test for impulsive buying had become a challenge for the researchers into consumers' behavior because of its complex characteristics. Hausman (2000) stated that impulsive buying behavior was a complex and varied behavior phenomenon; such consumers contributed the most to the volume of sales of retail products each year. Ruswanti (2013) mentioned that the character of cherry pickers tended to make them buy spontaneously after knowing that the shops offered big discounts. This was seen when the consumers shopped in a mall that frequently offered big discounts, from $50 \%$ to $70 \%$ off. The retail industry in Indonesia, as one of the most dynamic and fast developed industries, is controlled by both domestic and foreign companies. Retailers in Indonesia have shown increasing sales growth over the last ten years. This was encouraged by lifestyle changes and improvements in personal incomes.
The demographic conditions brought advantages to the consumers, such as their situation, the variety of products offered, and sociocultural changes. Indonesian consumers changed their shopping behavior; the comfortable marketplaces. AC Nelsen (2007) stated that apparently $85 \%$ of shoppers in Indonesian modern retail stores tended to do unplanned/impulse shopping. The first research gap, in the findings of the contradictory research results found by Mathai \& Haridas (2014) stated that discount prices did not influence impulse buying, and Verplanken et al., (2005) stated that promotional material inside shops had little influence on impulse buying. Meanwhile Ruswanti's findings (2013) stated that discount prices of $70 \%$ tended to influence the consumers to shop spontaneously. Secondly, confirming Ruswanti's findings (2013), the cherry picking behavior liked to move from one brand to another. Hawkins et al., (2007) also stated that impulse buying consisted of buyers who liked to look for variety, as the 
main reason for them moving from one brand to another.

The unplanned, impulsive shopping, relates stongly with cherry picking, in which the cherry picking characters were the happy and satisfied consumers, shopping both by moving from one shop to another and by moving from one brand to another to get the cheap quality products. Of course the cheap prices and the quality products could be gotten through the big discounts offerered in the malls' shops. The malls' shops usually give big discounts at the weekends, during holidays and important dates such as the $17^{\text {th }}$ of August (Indonesian independence day). In Lebaran, Christmas, and New Year, the malls' shops always offer discounts; it is done by the shops to attract the consumers to shop in the malls' shops. Besides, it is the shops' strategy to always be visited by consumers. The relatedness of the four impulsive buying dimensions developed by Muruganantham \& Bhakat, (2013), has never been tested empirically.

The impulse buying dimension was tested through four factors, which were external, internal, situational, products' variety, and the sociocultural environment. Impulsive buying is a common phenomenon in daily life (Liang, Liang \& Duan, 2008). Because of the economy and social developments, the consumption concept's development, and the situational improvement of factors such as shopping net, impulsive buying had become easier than before (Vohs \& Faber, 2007). Meanwhile the cherry picking variable had not been tested all that many times by former researchers; most of society did not yet know the term "cherry picking". The impulsive buying influence with the desire to cherry pick needed to be tested further, so that mall managers understood the consumers' behavior. Was it true that the discounted prices influenced spontaneous buying by the external, internal, situational and products' variety, and the sociocultural factors?

\section{THE RESEARCH PURPOSES}

The first purpose of this research is to test the influence of the four dimensions of impulsive buying with the cherry picking. A contra- dictory research result was found, which was the finding of Mathai \& Haridas (2014) that discount prices did not influence impulsive buying, meanwhile Verplanken et al., (2005) stated that promotional material by the shops did not influence impulse buying. But Ruswanti's finding (2013) stating that discounted prices of $50-70 \%$ off the list prices influenced the consumers to shop spontaneously. Dolakia (2000) stated consumers could experience being pushed into impulse buying when facing visual signs such as discounted promotional items. Secondly, to test empirically the findings of Muruganantham \& Bhakat, (2013) that stated impulse buying had four dimensions of external, internal, situational, products' variety, and sociocultural factors. Thirdly, there have only been a few people who have tested the relationship of impulsive buying and bargain hunting; theoretically both variables are very related.

Impulsive buying consisted of having spontaneous buyers, meanwhile the bargain hunters were the buyers who wanted to get the quality products with the big discounts (Ruswanti, 2013). Of course it was only the discounted products that were of good quality and at cheap prices. The bargain seekers tended to find information about all the shops to get the quality products at a big discount (Ruswanti, 2013). Shiffman \& Kanuk (2010) stated impulsive buyers was regarded as the consumers who liked shopping when there were innovative and creative sales promotions that used the right technological messages in the retail shops. The big discounts were aimed to attract the consumers who liked the promotional prices, to improve the shop's retail sales. The discount prices were the retail strategy for selling products. It is important to review again the influence between the impulsive buying dimension and bargain hunting.

\section{THEORETICAL FRAMEWORK AND HYPOTHESIS}

\section{Impulsive Buying Dimension}

The retail industry in Indonesia had become one of the most dynamic and fast growing industries, for both the domestic and foreign companies who entered the market, such as 
Carrefour, Makro, Lotte Mart, Indomaret, Alfamart, etc. Watching and testing impulsive buying behavior is very interesting; the proof is since 1950, it has been tested by Clover, meanwhile Abratt \& Goodey (1990) found that impulse buying testing, in the retail trades, could be more interesting for the producers and retailers all over the world. Muruganantham \& Bhakat (2013) stated that the spontaneous buying impulse or unplanned buying involved five dimensions, which were the external factor, the internal factor, the situational and offered products' variety factors, and the sociocultural factor. From that research result, the researchers would continue to test empirically, but when also related with bargain seeking behavior, there was very little research. Beatty \& Farrell (1998) stated that impulsive buying is direct buying without any pre-planning to fulfil certain needs.

Block \& Morwitz (1999) stated that impulsive buyers are consumers who buy certain products and suddenly have a strong impulse to buy something without first considering if they need or have a use for it. Meanwhile Rook (1987) stated that impulsive buying is the consumers' impulse coupled with their lifestyle characteristics and can be related with their materialism, or them looking for the sensational and recreational aspects of shopping. It is in accordance with Ruswanti's finding (2013) that consumers who are materialistic like to shop spontaneously, while recreate in mall, mainly to buy clothes. Han et al., (1991) stated the fashion oriented impulsive concept is the desire to buy new trendy products. Park et al., (2006) found that impulsive buyers are consumers with hedonistic characteristics and diligently follow fashion trends; they gain pleasure and happiness from finding the products they want. Kaur \& Singh (2007) found that teenagers, when they shopped, got a pleasurable and sensoric stimulation that influenced their impulse buying. Silvera et al., (2008) stated that impulsive buying was influenced by the consumers' positive emotions.

\section{External Environment}

Muruganantham \& Bhakat (2013) explained the external factor of impulsive buying is the marketing sign or the stimulation controlled by the marketers to attract consumers to buy their products. There are two stimulations of the external environment, those are the shopping and the marketing environment. The shopping environment, includes the shops' size, situation, design and format, while the marketing environment is the various sales activities and advertising. According to Muruganantham \& Bhakat (2013) impulse buying can be induced when consumers meet the relevant visual stimuli in a retail environment or promotional area. Impulsive buying is regarded as a shopping scenario with an innovative creative sales promotion which uses the right technological message in the retail spaces (Shiffman \& Kanuk, 2010).

Applebaum (1951) was the first man who showed that impulsive buying comes from the consumers' exposure to a stimulus in the shop, that is both direct and indirect. Hoyer \& Macinner (1999) stated that the atmosphere in shops is very influenced by attributes such as the lighting, location, the merchandise's presentation, tools/equipment, the floor, colours, voices, smells, the sellers' behavior, fashion styles, and service that improves the impulsive buying instinct. Verplanken et al., (2005) added that the products appearance and the background music in shops are the important external influences for the customers. Consumers can experience the impulse of buying something "on the spur of the moment" when faced with the visual or audio promotion in shops (Dholakia, 2000).

Sensoric stimulation and information levels are the main determinants of the environmental response condition. Variations like the music in the background and the shops location encourage the consumers to spend more time, and to buy something (Kaur \& Singh, 2007). It was also proposed by Xu (2007) that the shops' environment influences the consumers emotional condition and then pushes them into spontaneous buying behavior in the shop. Rook \& Hoch (1985) added that impulse buying is started by the consumers' sensations and perceptions being pushed by external stimuli, and then followed by the sudden urge to buy. The emotional feeling occurs so the promotion will be easily remem- 
bered until they buy the products. Impulsive buyers are the consumers who want to buy something, but then decide spontaneously what they want and will buy. (Lafferty \& Goldsmith, 2002).

\section{Internal Environment}

The internal environment factors that influence impulsive buying are the consumers who like shopping and finding variations and differences in products, and tend to have a liking to change brands (Hawkin et al., 2007). Consumers' finding variations in products was also found by Sharma et al., (2010). With impulsive buying behavior, an individual's personality has an incredible impact, the individual's personality characteristics are different to each other and the tendency of their impulsive behavioral levels are also different. Mathai \& Haridas (2014), started to try to explore the relationship between personal characteristics and impulsive buying behavior. Their finding was that one's personality influences the impulsive buying. Rook (1987) stated that impulsive buying is part of the lifestyle related with materialism, looking for sensations, and the recreational shopping aspect. Rook \& Fisher (1995) mentioned the impulsive buying concept is a character trait of someone who gets involved in spontaneous buying sprees.

The desire to buy clothing products can also be a variation of the spontaneous buying characteristic, compared with the daily needs purchases. But from Michael et al., (2010) buying without planning is the buying form with the lowest involvement. Impulsive buyers are also mentioned as the consumers who enjoy shopping and lack self-control (Yoan \& Faber, 2000). Unplanned buying is an activity that causes money to be spent uncontrollably, and mainly on items that are not really needed, but desired at that instant in time (Hatane, 2005). Ruswanti's finding (2014) stated that the consumers were materialistic in their shopping habits for trendy clothes, while using a mall for their recreation time with their family, and had a tendency for spontaneous shopping. Shen \& Khalifa (2012) stated the consumers' cognition had a relationship with impulse buying.
Verplanken et al., (2005) stated impulsive buying is to satisfy oneself, because of the stress of one's job, and to improve one's working spirit. Theoretically, the spontaneous buying is done because the consumers are stressed by their job, but it can also be because of a happy heart. Sneath et al., (2009) stated that impulsive buying is related with the consumers who have a hedonistic character, individuals with such a character tend to be materialistic. They also may have much wealth and tend to buy items they do not really need. Seath et al., (2009) stated that impulsive buying can be induced in an individual suffering from depression, in the hope that it will restore his/her better mood. Verplanken \& Herbadi (2001) stated impulsive buying happens with individuals who want to run from feelings of self-inferiority, the unhappy heart situation.

\section{Situational Environment and Products Variation}

The impulsive buying phenomenon is not only seen in Indonesia, but in many developing countries. But impulsive buying in Indonesia has tended to be more prevalent compared with the other countries in Southeast Asia. But in the Asia-Pacific region, the indications of impulsive buying were much higher; the research by Nelsen (2007) into modern retailers in Jakarta showed that the impulse buying level had reached $44 \%$ of the items bought by consumers on working days. On Saturdays and Sundays, the amount increased to $61 \%$. Apparently $85 \%$ of shoppers in Indonesian retail outlets tended to buy something without any previous thought or planning. The variations between similar products on offer by the retailers tended to influence the impulsive buying (Stern, 1962), meanwhile the products' functional benefits also pushed the impulsive buying need, as mentioned by Shiffman \& Kanuk, (2010). Variations in such products as clothes, books, and household equipment also influenced impulsive buying according to $\mathrm{Yu}$ \& Bastin, (2010). Impulsive buyers also tend to find the different products' variations (Sharma et al., 2010); sometimes consumers tend to move from one brand to another, just as an experiment (Hawkin et al, 2007). 
Impulsive buying intention can be influenced by information from one person to another (Harmancioglu et al., 2009). Meanwhile Han et al., (1991) mentioned that, when they studied the impulse buying of clothes, if consumers think the clothes suit them, they will buy them spontaneously. The functional benefits can also push the impulse buying phenomenon as mentioned by Shiffman \& Kanuk (2010). But Craford \& Melewer (2003) found candies (sweets) were the impulse buying products that sold the most, and that such a level of growth in their sales had never happened in previous years. The impulse buying products, such as candies, are convenience products, the products bought daily by consumers without planning or thinking and without any effort to find them (Kotler \& Keler, 2006). Han et al., (1991) stated that in studying the impulse buying of clothes, it was found that the consumers bought without planning, their emotions tended to push the impulse buying of fashionable items.

\section{Social Culture}

Consumers behavior is influenced by their motivation, personality, and socioculture; and marketers try to understand the different consumers' needs, and understand their various behavior toward their needs for the product. How the consumers buy and use the goods and services, how they react toward the prices, promotions, and the shops' interiors needs to be known by the retailers (Durmaz, 2014). The malls' condition and various cultural trends strength the influence on consumers to buy impulsively (Vohs \& Faber, 2007). The friendli- ness of the shopkeepers and the other consumers included in the social factor can influence the impulse to buy (Mattila \& Wirtz, 2008). Yu \& Bastian (2010) found that other peoples praise, such as the sellers, or the shoppers' friends can improve the chance of an impulse buy. The shoppers' friend who is asked for their opinion of the clothes that may be bought influences the impulsive buying, but the family's presence can decrease the impulse to buy (Luo, 2005).

The independent individual is often more involved in impulse buying, it is often triggered suddenly, there is the sudden intention to buy something not originally planned for when going shopping (Verplanken et al., 2005). Impulsive buying is influenced by various economic, personal, temporal, social, and even sociocultural factors. It can happen variously, and not only happens between the different buyers, when considering buying the same item, but also for the same shopper to buy the same item in a different situation (Stern, 1962). Because of that, it was often assumed that the personal and situational factors significantly influenced impulse buying, as mentioned by Maruganantham \& Bhakat, (2013). For that reason, it is necessary for the practitioners to understand their consumers from the sociocultural side, so that the products offered are suitable and match the consumers' needs. The cultural influence, the individualism theory, and the collectivism theory give insights into impulsive buying behavior (Kacen \& Lee, 2002). The cultural aspect can be of help to both the academics and practitioners in developing a better understanding of the impulsive buying phenomenon.

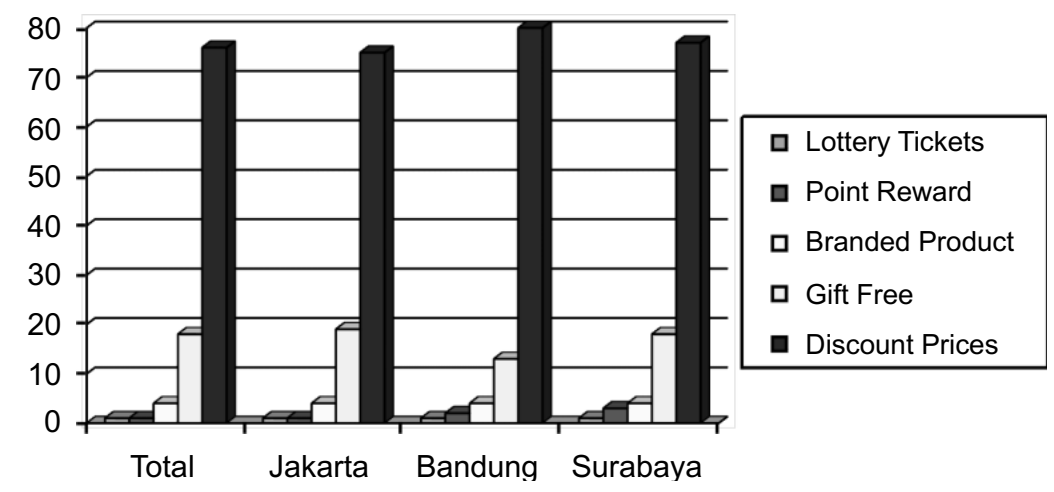

Table 1. Source: Nielsen (2007) Sales Promotion Activities 
Sales promotions in the world of modern retailing are sought after by consumers, Nielsen (2007) mentions that the majority of Indonesian consumers like promotional activities that provide direct benefits. This is evident from the $66 \%$ of respondents who chose a special promotion that offered additional extra products. They are also accustomed to looking for a special price at the outlet and are interested in buying a product if there are free samples attached to the product. Gifts and price discounts are suitable for consumers who pursue profit in the short term. Hendriani (2007), cited by Arifianti (2008), mentions in a survey conducted in the three major cities of Jakarta, Bandung and Surabaya (see Figure 1) that $76 \%$ of the buyers liked to get a discount while $18 \%$ liked the direct reward of a free gift.

Nielsen (2007) mentions that in some developing countries, particularly in Indonesia, the apparently low prices of goods is one of the three main reasons consumers stay loyal to the modern retail outlets. That is why a massive discount war is ongoing in the modern retail outlets of Indonesia. Hypermart has been discounting prices by up to $31 \%$. Though marginal retailers generally range from 2 to $5 \%$ discounts. Setiawan,( 2007) cited by Arifianti, (2008).

\section{BARGAIN HUNTING}

Bargain hunters can be defined as the best decision makers; when buying products they will get the cheap quality products. The consumers' knowledge of prices when selecting the discount products can be influenced by several factors related with the consumers' characteristics, and for the category of food products, it has been tested by Estelami (2008). The prices in the market play a relevant role in the buying decision; women understand more about jewelry prices than men, generally. The consumers' price knowledge and gender influence the marketing strategy of the retailers (Chant \& Scheers, 2011). The price knowledge is defined as the consumers' ability to buy products, and to remember the price they paid for certain products in their long-term memory. The products' prices in the markets play a relevant sensitive role in the consumers' decision making, influencing what, when, where, and how much the consumers will pay for the products (Alba et al., 1999).

Studying the price knowledge is very relevant for the consumers and makes it easier for them to pick bargains. Discounted price information for a product, and the products' variety aid the easiness in finding an item at the right price. Various products offered by the shops include snacks, shoes, work bags, work clothes, and household products. The result of research by Chant \& Scheers, (2011) in South Africa showed women knew more about the various products than men did. Women related positively with the knowledge of prices, so women were better at pick the cherries rather than the men. The other factor that influenced the bargain hunting consumers were the shops that offered the complete range of the various products and offered discounts of as much as $50 \%-70 \%$. Some former researchers have tested the bargain seeking influence toward the consumers prices knowledge, and the gender difference in choosing food supplies in the USA and Europe.

Indonesian consumers, if shopping in retail stores, usually swarm to find the most wanted

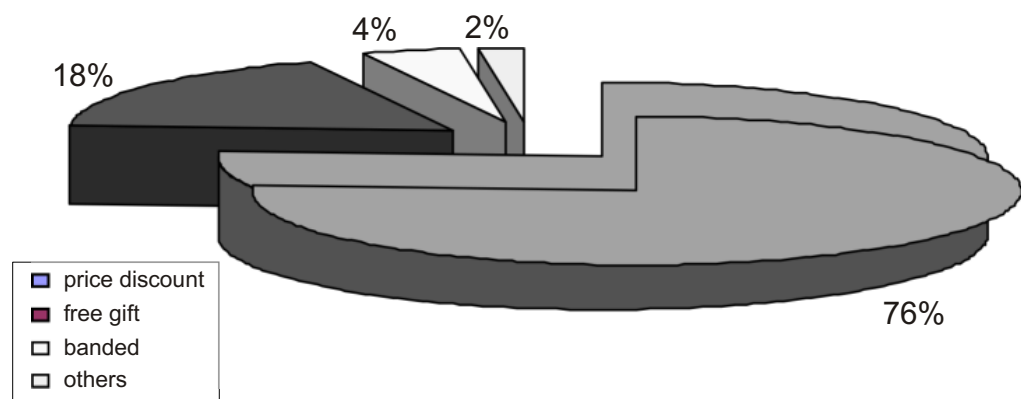

Figure 1. Source: Nielsen (2007) Sales Promotion Activities 
products, mainly the big discount items such as clothes. Although sometimes the sizes are not all held in stock, and the style's variations and colours are also not in stock. But consumers feel lucky if they can get the big discount products, especially if they are brand name products. The researcher's interview results with some of the respondents showed that consumers were more interested in finding the products they felt they wanted and needed, with the quality level and discount they desired. The price discounts in retail outlets were usually known by the consumers, mainly the bargain hunters who sometimes liked to move from one shop to another to get the goods they wanted Fox \& Hooch, (2003). But, different to Levy \& Weitz's opinions (2004) whose findings showed that the bargain seekers were the consumers who visited a shop and only bought the big discount items; the other factor that influenced the bargain hunters was they enjoyed shopping in their favorite shops.

Crocer (2005) found that bargain hunters were described as the sellers and the buyers; a seller could be seen as the selective person toward the consumers' profiles that they chose as the market targets. On the buyers' side, the consumers shopped selectively toward the specially priced products. Not all the shoppers in retail outlets are hunting bargains. They are the buyers who are sensitive toward prices, and tend to delay buying until they can find a cheaper offering, but still with the variety they look for. It was found that there was a significant relationship between loyalty and moving from one shop to another, as the bargain hunters do. Halbritter \& Carter (2005) proposed they actually did two activities. Firstly, they shopped in the retail outlets every week, where they got the best prices.

Sometimes the retailers competed in promoting the same products with different prices. The changes every week increased the chances of the bargain hunters getting a good deal, compared with the loyal consumers who shopped in only one shop. The bargain hunters showed the excesses in consumers' behavior when buying products; it was important that they be known by the retail managers when planning the marketing strategy. Consumers got their price information for the various industry products, the prices offered by the retailers on the various products or services and the retailers' locations to make it easier for them to find a bargain. Most consumers were informed about the discounted products in several outlets, through marketing in the form of promoting the list prices. The retailers knew the bargain hunters as the shoppers who liked to compare the prices in several shops and usually got a special prices. There have been very few studies into cherry picking in Indonesia, so this study will test the cherry picking dimensions, related with impulse buying.

\section{RESEARCH HYPOTHESIS}

The prices of goods in the market plays a relevant role in the decision making, influencing what is bought in the retail outlets, when it is bought, where, and how many are bought by the consumers (Alba et al., 1999). It is important for the retailers to understand the bargain hunters' behavior, and it can be useful to arrange a marketing strategy for them, to obtain a bigger market share which in turn leads to a bigger return on investment. A retail management strategy is useful in achieving their marketing purposes. The goal of a company's marketing strategy is to provide a strong base for the developed tactical plans, which allow the company to carry out its plans effectively and efficiently. Lavy \& Weitz (2004) stated that the bargain hunters are the consumers who visit a shop and only buy the big discounted products.

Impulsive buying is defined as the consumers' characteristic of deciding to indulge in spontaneous shopping. The consumers' characteristic variated in their tendency to have a spontaneous buying impulse (Johnes et al., 2003). Consumers who tend to buy impulsively are very much in demand by the retailers, because their unplanned shopping sprees can increase the retailers' profits. It can be stimulated by unexpected buying ideas, the wanted products' variance situation; they are also dominated by their emotion toward products to satisfy themselves or their egos. But the consumers with the greatest tendencies to impulse buy do not always respond to every stimuli, because of various factors that 
may limit them, such as their economic condition or time pressures, that can obstruct their desire to indulge in spontaneous buying. Foroughi et al., (2011) found that the consumers who tended to buy spontaneously also enjoyed shopping.

Theoretically the impulsive buying trigger comes from a sales promotion, as stated by Muruganantham \& Bhakat, (2013). These could be advertisements and special or discounted prices offered by the shops. Meanwhile the internal factor is influenced by the consumers themselves, such as the will to buy spontaneously. Those seeking bargains are the consumers who like to move from one shop to another to get their cheap quality goods (Fox \& Hooch, 2003), and who enjoy shopping. Relatedness is that the cherries pickers in finding the big discount products sometimes also buy spontaneously, such as buying the clothes if liking the offered clothes, although it is unplanned (Han et al., 1991). Impulsive buying behavior has received a great deal of atttention from marketing experts, but until today it has not been tested much in relation to bargain hunting. For that reason, it needs to be reviewed further for its external and internal factors' influence toward seeking a bargain. The research hypotheses that are proposed are as follows:

H1: There is a significant positive influence of the external environment toward bargain hunting

$\mathrm{H} 2$ : There is a significant positive influence of the internal environment toward bargain hunting

Ruswanti's findings (2013) stated that bargain hunting also has the impulsive buying characteristic, such as if someone suddenly sees big discounts, say between 50 to $70 \%$, on clothes in a shop, they will spontaneously buy them if they like them. Meanwhile the bargain seekers are the consumers who always get the cheap quality goods; the situational influence and big discounts are the causes of bargain hunting and spontaneous buying. The retailers gave the big discounts on special days, for example during Lebaran and at New Year. Rook (1987) found the impulsive buyers experienced a momentary desire, which was strong and firm, after seeing/ feeling the shops' stimulation. Actually consumers were interested in buying the products because of the big discounts offered (Ruswanti, 2013). Rook \& Gardner (1993) stated that impulsive buying is defined as unplanned behavior, involving fast decision making, with the tendency to buy the products they suddenly want.

The shopping culture is the habit of consumers, who may have low, medium, or high incomes. They became hedonistic, mainly because of their need for the clothes, bags, and shoes that are currently in vogue. Using the available discounts to fulfil their desire to own these cheap brand name products is known as seeking bargains, meanwhile the unplanned impulsive buying has a strong relationship with happy and satisfied consumers if they indulge themselves by moving from one shop to another or by moving from one brand to another to shop for the cheap quality products. Meanwhile according to Hawkins et al., (2007) the buyers who look for variation and the consumers who move from one brand to another are also called impulse buyers. There is a clear relationship between impulsive buying and bargain hunting, consumers who look for products' variation and move from one brand to another are called impulsive buyers. Han et al., (1991) stated that, when studying impulsive buying from the clothing aspect, if consumers liked it, they buy it, spontaneously. For that reason, there needs to be further testing of the impulsive buying influence and bargain seeking. The proposed hypotheses are as follows:

H 3: There is a situationally significant positive influence and product variety toward bargain seeking

$\mathrm{H}$ 4: There is a socioculturally significant positive influence toward bargain seeking

The main purposes of promotions are to attract the consumers' attention, build a positive attitude, and to create an emotional reaction to make the customers attracted to buy the products offered by the retailers. Sales promotions influence bargain hunting. Buyers can be involved 
with the more extreme hunting in which moving from one shop to another can be done by each shopper. Consumers can divide the goods in several shops each week to gain advantages from the transactions offered by different shops. Gauri, Sudhira \& Talukdar (2005) proposed that bargain hunting is divided into three parts. First, those who picked the cherries by following the prices from time to time, which shows that consumers were loyal toward the shops, but sensitive toward prices. Furthermore, they delayed their shopping from time to time until the shops gave the big discounts.

Second, consumers can pick the cherries through following the shop's prices from one shop to another, which shows that consumers are still shopping, but, with the price considerations they are shopping in different shops. Third, the bargain hunting consumers can be the customers who are shopping by moving from one shop to another at different times. Selvera \& Marreiras (2014) stated that impulsive buying happens if the shoppers decide to buy certain things because of the special prizes, the discounts on offer, coupons, etc. Impulsive buying happens in the first five minutes of shopping and its probability decreases with time (Brocas \& Carillo, 2014). Four impulsive buying dimensions consist of external environment, internal environment, situation and products' variation, socioculture. Those are assumed to influence bargain hunting. The researcher has tried to illustrate this in the research model below.

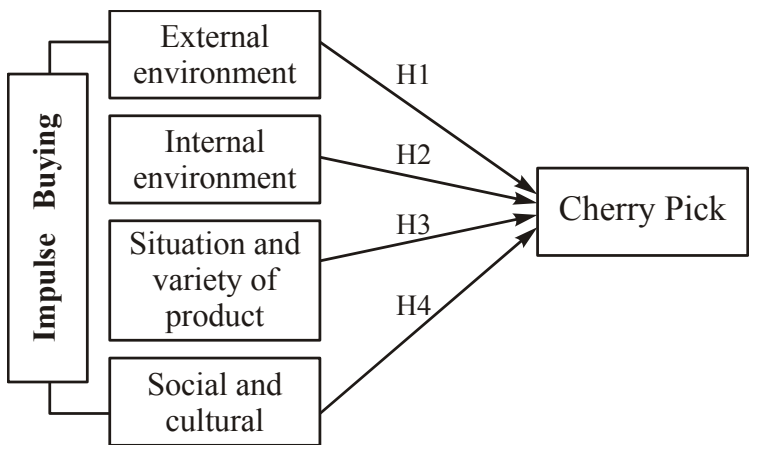

Figure 2. Research Model

Mathai \& Haridas (2014) mentioned that the discounted prices of products induced impulsive buying and the shops' fragrance influenced impulsive buying. Chen \& Lee (2013) mentioned that promotions influenced the extrovert consumers; they were more likely to buy impulsively. Graa et al., (2014) stated that impulsive buying was defined as having no plan to buy anything before entering the shop, but the impact created by the promotional sale stimulated the desire. The external factor of impulsive buying refers to the marketing signs or stimulation placed and controlled by the marketers in the effort to attract consumers to buy (Youn \& Faber, 2000). Consumers can experience the impulse to buy products when facing the visual signs such as promotional discounts (Dholakia, 2000). Because the impulsive buying behavior is often pushed by a stimulus, the exposedness increases toward the certain external stimulation and increases the impulsive buying possibility.

\section{RESEARCH METHODS}

The research method used is the causal research method that tests the influence between variables. The independent variable is impulse buying and the dependent variable is bargain seeking. The causal research method studies how far a variation in one variable, relates with the variation in the other variable. It is based on the corelation coefficient, in which variables are measured, but not manipulated (Hair et al., 1998). This research consists of the independent variable including the external environment, internal environment, situation and products variety, and the socioculture factors. Meanwhile dependent variable is the tendency to search for good deals such as liking big discount prices to buy the good cheap quality products, and the information obtained from the shops, such as to move from one shop to another, following the prices from time to time, delaying shopping until there are discounts.

\section{Population and Research Samples}

The population amount in this research is unknown, but the respondents in this research are the respondents who frequently shop. The chosen items to shop for were the big discounted goods, the discounts must be between $50 \%-70 \%$. Both men and women liked shopping in a mall in Jakarta. They were housewives and university 
students with the respondents' characteristics as follows: the respondents' ages were between 1750 years old, who were living in Jakarta. They were happy to buy and they tended to have previously bought impulsively because of the influence of a sales promotion. The research samples were as many as 200 respondents. This number of 200 respondents was suitable as a research sample, based on Hair et al., (1998) but the data that could be tested came from 197 respondents, because three questionnaires was not filled in completely.

\section{The Research Variables Measurement}

The research indicator of the impulsive buying variable was adopted from Muruganantham \& Bhakat's finding, (2013). Impulsive buying consists of 34 indicators arranged on four dimensions but fixed with the malls' condition in Jakarta. The external environment factor has 8 indicators, the internal environment factor 5 indicators, the situational environment factor and products' variety factor 6 indicators and socio and culture environment factor 5 indicators, bargain hunting 10 indicators, adopted from Ruswanti (2013). A survey was used to test all the hypotheses, done through the respondents who tended to buy spontaneously and tended to like the discount prices when shopping in retail outlets. The reasons for using this survey method are that the data can be used to test several hypotheses and can measure the respondents behavior.

This research population was the consumers who were shopping in retail outlets and liked the discount products, and were looking for discounted prices being offered, as much as $50 \%$ $70 \%$ off the regular prices, and had bought spontaneously at least once before. The next stage was qualifying them and then interviewing them. For consumers who were willing to complete the questionnaire, the questionnaire forms were distributed and after filling them in, prizes were given to them as a reward for their time. The research design used a survey, the research location was in the retail area of Central Jakarta. The scale used was the interval scale with a Likert scale of 1 until 5. Number $1=$ strongly disagree, $2=$ disagree, $3=$ agree slightly, $4=$ agree and $5=$ strongly agree. The sampling technique was a purposive sampling of those respondents who liked to buy spontaneously and at discount prices. The malls were chosen based on the comfort and the broad rooms to make respondents free spreadth.

The samples measure was 200 (Hair et al., 1998), but only 197 data returns could be analyzed, as three of respondents did not complete the questionnaire. Beside the questionnaire, there were interviews with 30 of the respondents to confirm the impulsive buying and bargain seeking theories; the analysis tool was the SPSS series 19 . This research was carried out only on weekdays, during the mornings and evenings, so time differences would not influence the research results. At the weekend consumers usually did the family's shopping; filling in the questionnaire would have disturbed them. The samples consisted of 96 women and 101 men. The respondents' ages were between 17-50 years old, the respondents incomes were less than 3 million rupiahs, for 83 of them, above 5 million rupiahs for 64 of them, and above 10 million rupiahs for 50 persons. Their education level was either that of a university graduate or they were still studying.

Before the data was analyzed, its validity and reliability needed to be tested; the research item's validity used a factor analysis. Factor analysis can reveal the disguised characteristics owned by each observation unit of a group of dimensions. The external factor dimension, from the analysis result, the value of Kaiser-MeyerOlkin Measure of Sampling Adequacy received a value of 0.612 in the KMO box and Bartlet's test.This result shows that this instrument was valid because the KMO value was above 0.5 . Besides, Bartlett's test value showed the value of 78.089 , with a significance value of 0.000 , so it can be concluded that this instrument has fulfilled the validity requirements. Furthermore, the correlation result of each factor is high $(>0.5)$. from the analysis testing result, it is known that the external factor value consists of 0.714 (EKT 1), 0.575 (EKT 2), 0.615 (EKT 3), 0.611 (EKT 4), 0.542 (EKT 5), 0.701 (EKT 6), 0.694 (EKT 
7), and 0.576 (EKT 8). So based on the factor validity testing result, it is concluded that all the factors are valid as the framer of the external factor variable.

The internal factor dimension, from the analysis result for the value of Kaiser-MeyerOlkin Measure of Sampling Adequacy has a value of 0.711 in the KMO box and Bartlet's test. This result shows that this instrument is valid because its KMO value is above 0.5. Besides, Bartlett's test value is 114.771 with a significance of 0.000 ; it can be concluded that this instrument is valid. Furthermore, the correlation result of each factor is also high $(>0.5)$. from the analysis testing result, it is known that the correlation value of each internal factor consists of: 0.704 (INT.1), 0.717 (INT.2), 0.670 (INT.3), 0.725 (INT.4), and 0.721 (INT.5). So based on the result of the factor validity testing, it can be concluded that all the factors are valid as the framer of the internal factor variable.

The situational factor dimension, from the analysis result of the Kaiser-Meyer-Olkin Measure of Sampling Adequacy, has a value of 0.778 in the KMO box and Bartlet's test. This result shows that this instrument is valid because the $\mathrm{KMO}$ value is above 0.5. Besides, Bartlett's test value is 305.101 with a significance value of 0.000 , so it can be concluded that this instrument is valid. Furthermore, the correlation result of each factor is also high $(>0.5)$. From the analysis testing result, it is known that the correlation value of each situational factor and product's variety consists of: 0.826 (SIT.1), 0.835 (SIT.2), 0.866 (SIT.3), 0.719 (SIT.4), 0.729 (SIT.5), and 0.879 (SIT.6). So based on the result of the factor validity testing, it can be concluded that all the factors are valid as the framer of the situational factor variable.

Social factor dimension, from the analysis result Kaiser-Meyer-Olkin Measure of Sampling Adequacy has a value of 0.627 in the KMO box and Bartlet's test. This result shows that this instrument is valid because its KMO value is above 0.5. Besides, Bartlett's test value is 89.546 with a significance value of 0.000 , so it can be concluded that this instrument is valid. Furthermore, the correlation result of each factor is high
$(>0.5)$. from the analysis testing result, it is known that the correlation value of each socioculture factor consists of: 0.640 (SOC.1), 0.583 (SOC.2), 0.634 (SOC.3), 0.617 (SOC.4), and 0.628 (SOC.5). So based on the result of factor validity testing, it can be concluded that all the factors are valid as the framer of the social factor variable.

Next, the correlation result of each factor is also high $(>0.5)$. From the analysis testing result, it is known that the correlation value of each bargain seeking factor consists of: 0.904 (CP.1), 0.797 (СР.2), 0.874 (CP.3), 0.854 (СР.4), 0.813

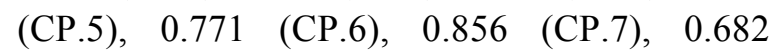
(CP.8), 0.738 (CP.9), and 0.767 (CP.10). So based on the result of the factor validity testing, it can be concluded that all factors are valid as the framer of bargain seeking factor variable. From the analysis result, Kaiser-Meyer-Olkin Measure of Sampling Adequacy's value was 0.814 in the KMO box and Bartlet's test. This result shows that this instrument is valid because the KMO value is above 0.5. Besides, Bartlett's test value is 613.662 with a significance value of 0.000 , so it can be concluded that this instrument has fulfilled the validity requirements.

\section{RESULTS AND DISCUSSION}

After the data were analyzed using the regression analysis, the analysis result shows that the five dimensions of impulsive buying that consist of the external factor, the internal environment factor, situational and products varieties, and the sociocultural influences positively and significantly influence the bargain hunting (see Table 2) below.

From simple regression calculations, Table 2 shows that the dimensions of impulse buying consists of external environmental factors, internal environmental factors, the situational environment and the variety of products, and the sociocultural environment, and all influence the bargain seeking. Internal environmental factors and the sociocultural environmental factors have a significant influence, while the external factors, the situational factors and the range of products also have a significant positive effect, and can be described as follows. 
Table 2. Regression Analysis Results

\begin{tabular}{|c|c|c|c|c|c|}
\hline \multirow[t]{2}{*}{ Impulse Buying } & \multicolumn{2}{|c|}{ Unstandarized coefficient } & \multirow{2}{*}{$\begin{array}{c}\begin{array}{c}\text { Standarized } \\
\text { coefficient }\end{array} \\
\text { Beta } \\
\end{array}$} & \multirow[t]{2}{*}{$\mathrm{t}$} & \multirow[t]{2}{*}{ Sig } \\
\hline & $\mathrm{B}$ & Std. Error & & & \\
\hline (Constant) & 3.282 & 0.280 & 0.153 & 11.734 & 0.000 \\
\hline EXTERNAL & 0.183 & 0.083 & & 2.211 & 0.028 \\
\hline (Constant) & 2.675 & 0.287 & 0.349 & 11.272 & 0.000 \\
\hline INTERNAL & 0.320 & 0.062 & & 5.203 & 0.000 \\
\hline (Constant) & 3.319 & 0.208 & 0.198 & 15.960 & 0.000 \\
\hline SITUATIONAL & 0.166 & 0.059 & & 2.815 & 0.005 \\
\hline (Constant) & 2.194 & 0.262 & & 8.381 & 0.000 \\
\hline SOCIOCULT & 0.481 & 0.073 & 0.425 & 6.556 & 0.000 \\
\hline
\end{tabular}

Dependent Variable: Cherry Picking

\section{The First Hypothesis}

This shows that the external environment dimension of impulsive buying influences the bargain hunting positively and significantly, as shown by the test results value of 0.028 , which is fewer than 0.05 . This is understood to mean that the voice promotion in a shop, the shops' organisation, smells, display presentations, and the shopkeepers' behavior influence bargain seeking behavior, such as a discount offering $70 \%$ off listed prices, various discounted products, discount information. The voice promotion from the shop influences impulsive buying. This is in accordance with Verplanken et al., (2005), but in contrast with Mathai \& Haridas's finding (2014) that in-store promotion does not influence impulse buying. Order, display presentations, the shops' smell and the shopkeepers' behavior influence the bargain seeking. It supports the finding of Hoyer \& Macinner, (1999) that order, display presentations, shops' smell, and the shopkeepers' behavior influence impulsive buying.

Bargain hunters like to shop in malls with either the scent of jasmine or roses, and neat tidy shops that make it easier for consumers to see the big discounts on offer. The display presentations attracts the consumers' interest and they tend to choose the products in the display. The finding of Tauber, with Muruganantham \& Bhakat, (2013), that the colour of the clothes, the clothes' mode displayed in the shops' windows influences the impulse buying. The friendly shopkeepers were very helpful in choosing products and had the impact of motivating the consumers trust in choosing the products they wanted. Consumers could experience the desire for a sudden, impulse buy when facing visual signs such as promotional incentives, Dholakia, (2000), so it was proved that the bargain hunting consumers were also shopping because they were influenced by the discounts on offer.

\section{The Second Hypothesis}

This shows that the internal environment has a significant influence, with a value of 0.000 , which is smaller than 0.05 . From this result, it can be interpreted that work stress, work spirit, today's lifestyle, buying the branded clothes and the different clothing brands influence bargain hunting. In accordance with Sherma et al., (2010); Hwkin et al., (2007); Rook (1987); Chang et al., (2011) who stated that the work spirit improvement, work stress, lifestyle, branded clothes, and clothes' modes influence impulsive buying. Spontaneous buying can be done by consumers for reasons such as (1) consumers need the products, but have not found them yet (2) consumers do not need the products but are attracted to buy the discounted products (3) consumers need the products and the products have a big discount. The practitioners of course will make a different strategy if they have the consumers' criteria. The internal environment tends to make choices because of the consideration to buy good cheap quality products; 
instead of the consideration, consumers also have the prices' knowledge.

Meanwhile Chang et al., (2011) stated consumers who had a positive emotional response toward the shops' environment, were more likely to buy spontaneously. The materialistic lifestyle looks for sensations and makes shopping in a mall a recreational tool Rook (1987) and Ruswanti, (2014). Levy \& Weitz (2004); in their findings show that the bargain hunters visited a shop and only bought the goods on offer with big discounts; the other factor that influenced the bargain hunters is that they enjoyed shopping in their favourite shops. Colly \& Burges (2003) stated consumers who bought all kinds of products reasoned they really needed the products, so as to ease their depression, to express their identity or to have fun. It was found that the sales' significance through the impulsive buying showed that impulsive buying was the key subject for retailers and producers. So, consumers who enjoyed shopping in malls, instead of the bargain hunters were also impulsive buyers.

\section{The Third Hypothesis}

This shows that the situational factor and the products' variety influence positively and significantly the bargain hunting, with values equal to 0.005 , which is less than 0.05 . This reveals that there is an influence from the situational and products' variety on impulsive buying toward the situational dimension and the products' variety, that are positive and significant toward bargain hunting. It was seen that consumers had a limited time to shop, the existence of the trend mode offering, but remembered the benefits of the products they had bought previously, and the existence of information from close friends, certain clothes tended to push bargain hunting behavior. This result can be interpreted that promotion by one person to another, the products' benefits and variations and the time available all influence bargain seeking behaviour.The findings of Harmancioglu et al., (2009); Stern (1962); Han et al., (1991) explained that the promotion from one person to another, shopping according to the perceived benefits, the availability of variations in the products being offered, and the time available motivated impulsive buying.

When shopping in a mall, influences such as the mall's location, the available shopping time, and shopping habits drove impulsive buying (Shapiro, 1992). Park et al., (2006) found the fashion motivated impulsive buying such as liking a certain style, the newest lines of clothes, and the clothes' brands. Meanwhile according to Hawkins et al., (2007), the buyers who looked for different alternatives became the main reason to change brands; they were called impulsive buyers. The relation between impulsive buying and bargain hunters can be described as follows, consumers who look for the products' variations and change brands are called impulse buyers. Bargain hunters are the consumers who get the cheap quality products and look for the products' variations. Both groups were shopping situationally and looking for various products, and were interested in shopping because of the discounted prices.

\section{The Fourth Hypothesis}

This shows that the sociocultural factors influence is positive and significant, showing a value of 0.000 toward bargain hunting. This result can be interpreted that the sociocultural dimension consists of the urgent needs, shopkeepers' friendliness, having a shopping partner, having a monthly wage, shopping for clothes to support carrier, and the act of engaging socially influences bargain hunting. It supports the statements of Yu \& Bastin (2010); Luo (2005); Verplaken et al., (2005). They stated the shopkeepers' friendliness, having a shopping partner, having ones own money, and the existence of urgent needs all triggerred the occurence of impulsive buying. Impulse buying tended to be done by people with incomes above five million rupiahs and who were influenced by the interesting discounts, the variety of discounted products on offer, and information about the discount prices'. There was a tendency for consumers to buy impulsively when they were hedonistic and enjoyed shopping Dittmar et al., (1995). 
The survey by Nielsen, (2007) showed that Indonesia was in the top position as the country with the highest consumption levels in society, compared to other countries. Gerald, (2013). For practitioners, bargain hunting has the ability to encourage price competition among the retailers, so they try to have the cheapest offers with weekly advertisements. The retail management strategy has the idea to attract bargain hunters to get the bigger turnover. The retailers realized the bargain hunters liked the discounted products, the burden of reduced prices was endured by the retailers and producers. This study tries to explore the influence of the sociocultural dimension; which significantly influences bargain seeking. The indicators are an urgent need, the shopkeepers' friendliness, having a shopping partner, the complete offered clothes in mall, and the consumers' financial independence. They tend to motivate the bargain seeking behavior.

Results of the analysis of Table 3. above shows that internal factors and sociocultural factors, situational factors and the range of products and external factors. have a significant positive effect. Hypotheses $1,2,3$ and 4 are all supported.

\section{CONCLUSION}

Impulse buying in modern retailers in Jakarta can reach $44 \%$ of the total number of items bought by consumers within a working day. Meanwhile during weekends, the number of impulse purchases increased to $61 \%$. In fact, $85 \%$ of the consumers who shopped in Indonesian malls or modern retail outlets were inclined to buy a product without any previous plan. This was found by Nelson (2007). Theoretically, according to Kotler \& Keller, (2006), the goods purchased without a plan were convenience goods but these findings show goods such as good quality clothes would be bought impulsively, triggered only by the discount price. It is proved that the dimensions of the external, internal, situational and sociocultural environments have significantly influenced bargain hunting; these findings were supported by the findings of Muruganantham \& Bhakat, (2013) as well as Ruswanti (2013) but were opposed by the findings of Mathai \& Haridas (2014).

Impulse buying is the attitude of shoping without a plan, and results in the sudden preference to buy something for one's own self-satisfaction, meanwhile bargain hunters shopped to obtain good quality articles at a low price. It is concluded that there are some differences in the advantages obtained when reviewed from the point of impulse buying obtained by retailers and producers, whereas the advantages of bargain seeking were gained by consumers and retailers.

\section{MANAGERIAL IMPLICATION}

This study brings implications both theoretical and practical; theoretically this study contributes to the development of the consumers and their attitude theory, through the understanding of impulse buying and bargain hunting. Theoretically goods are the articles that were bought with certain considerations for their price, quality, who the seller was and which brand it was; however, in relation to the increasing income of people today, spontaneous purchasing can occur. For practitioners, impulse buying and bargain hunting were triggered by the discounted prices which means that impulse buying has established a competitive price among the retailers and therefore they are attempting to develop the lowest competitive price by offering $70 \%$ discounts. The strategy of retail management is aimed at urging the impulse buyers and bargain seekers to buy from their stores, so they can

Buying and Bargain Seeking

\begin{tabular}{cc}
\hline ignificant & Hypothesis \\
\hline 0.028 & Hypothesis 1 supported \\
0.000 & Hypothesis 2 supported \\
0.005 & Hypothesis 3 supported \\
0.000 & Hypothesis 4 supported \\
\hline
\end{tabular}


increase their turn-over and profits. The retailers realized that the bargain hunters and impulse buyers prefer discounted products; the cost of bargain buying is carried by both the retailers and the producers. However, there is a tendency that the dimension of impulse buying has influenced positively the bargain buying attitude. This indicator, which was shown by the finding that spontaneous buying was also triggered by discounted prices has supported the findings of Ruswanti (2013), who stated that the need for clothes, shoes, shirts, office bags by consumers under 31 years old should be satisfied with high discount prices based on the adequate income of most respondents. Discount offers have triggered impulse buying and bargain seeking, and the strategy of retail marketing can combine those targets of company marketing by using the data resulting from the dimension of impulse buying and bargain hunting.

\section{SUGGESTION}

1. For consumers, particularly for impulse buyers and bargain seekers, that they limit their monthly expenditure. Because when there is no plan for expenditure, they can be affected by the big discounts offered. When seeing the big discounts, all articles will appear to be good value. Buy the basic necessities which have long shelf lives, or do not go out of date/style quickly, as these can be kept as stock or be used as a gift/souvenir. This will help reduce wasteful monthly expenditure.

2. For retail managers, the findings of this study can be used as a basic strategy for marketing. The products with limited variations and incomplete colours (ie rejects) and styles can be sold immediately with high discounts such as $50 \%-70 \%$ to prevent the products from expiring as well as to provide advantage for the retailers in urging the consumers to buy them again. It should be a concern when the products constitute fashion or food items because of the risks of out of date models and expired food. From this result, the retailers do not sell the culinary products only but also the fashion products with great discount which can develop the impulse buying.
3. For academics, convenience goods are theoretically not always the products which will be bought on a daily basis with no specific consideration, but also be bought based on the level of the consumer's income. Consumers with sufficient income will buy clothes which can be chosen spontaneously without any consideration; however, for the consumers with limited incomes, those products are not always purchased, even if a great discount exists. When the consumers have certain reasons such as they suffer from depression (low emotion atmosphere) or having extra money, they will not apply self-control in buying products spontaneously and are satisfied to be hunting a bargain.

\section{THE LIMITATION OF THE STUDY}

This study has limitations, namely the study was only conducted locally in Central Jakarta, and it is only a study on the case of impulse buying and bargain hunting, so it cannot be generalized. The population and sample of respondents for the next study should be enlarged and the dimension of personality should be included as should the dimension of impulse buying, while the impact of post-spontaneous buying needs to be tested to see whether it is followed by satisfaction or regret.

\section{REFERENCES}

Abratt, R., \& Goodey, S. D., (1990). Unplanened Buying and in-Store stimuli in Supermarkets. Managerial and Decision Economics Journal, 11(20), pp. 111-112.

Alba, J. W., Mela, C. F., Shimp, T. A., \& Urbany, J. E., (1999). The Effect of Discount Frequencies and Depth on Consumer Price Judgements. Journal of Consumer Research, 26, pp. 99-114.

Arifianti, R., (2008). Pengaruh Pengaruh Promosi Penjualan Terhadap Impulse Buying Pada Hypermarket di Kota Bandung Universitas Pajajaran Bandung

Applebaum, W., (1951). Studying Consumer Behavior in Retail Stores. Journal of Marketing, 16(2), pp. 72-178. 
Beatty \& Farrells., (1998). Impulse buying: Modeling it Precursors. Journal of Retailing, 74(2), pp. 169-191.

Block, L. G., \& Morwitz, V. G., (1999). Shopping list as an external memory aid for grocery Shopping: influences on list writing and list fulfillment. Journal of Consumer Psychology, 8(4), pp. 343-375.

Brocas, I., \& Carillo, J. D., (2014). A Theory of Haste with application to impulse buying and destruction of the environment. European Economic Review, 44, pp. 1104-1115.

Carter, B., (2005). The Facts Analytical Study. University of Jordan, 31(2), pp. 278-297.

Chant, M. C., \& Scheers., (2011). Identifying the Correlation Between the Gender and Kwoledge of the South African Consumer in The Selection of Grocery Products. International Peer Reveiwed Journal, 1.

Chang, H. J., Eckman, M., \& Yan, R. N., (2011). Application of Stimulus Organism Response Model to The Retail Environment: the role of hedonic motivation in Impulse buying Behavior. Intenational Journal Revieu of Retail, Distribution, and Consumer research, 21(3), pp. 233-249.

Chen \& Lee, M. C., (2013). Personality antesedents of online Buying Impulsiveness. Journal of Economic.

Clover, T., (1950). Relative importance of impulse buying in Retail Stores. The Journal of

Marketing, 15(1), pp. 66-70.

Craford, G., \& Melever, T. C., (2003). The Importance of Impulse Purchasing Behavior, in The International Airport Environment. Journal of Consumer Behavior, 3(10), pp. 85-98.

Crocer, D., (2005). Cherry picking. Available From: http//proquest.Umi.com.

Dittmar, H., \& Friese, S., (1995). Gender Identity and Material Symbols: Objects and Decision Considerations in Impulse Purchase. Journal of Economic Psychology, 16, pp. 491.

Durmaz, Y., (2014). The Influence of Cultural Factor on Consumer Buying Behavior and an application in Turkey. Global Journal of Manajement and Research: E marketing, 14(1), pp. 2249-4588.
Dholakia, U. M., (2000). Temptation and resistance: An integrated model of consumption impulse formation and enactment, Journal of Psychology and Marketing, 17(11), pp. 955-982.

Estelami, H., (2008). The price is right or is it? Demographic and category effects in consumer price knowledge. Journal of product and Brand Management, 7(3), pp. 254-266.

Foroughi, A., Buang, A., \& Sheriliou, M., (2011). Exploring impulse buying behavior among Iranian tourists in Malaysia. An international converence on Business and Economics. Research Proceeding.

Fox, E. J., \& Hoch, S. J., (2003). Cherry picking. Journal of Marketing, 69 (1).

Gauri, D. K., Sudhir, K., \& Takukdar, D., (2005). When and Where To Cherry Pick? The Temporal and Spatial Dementions of Price Search. Available from:www.Geogle. com.95

Gerald, V., (2013). Fenomena Konsumtif Kelas Menengah Indonesia. (Online), (http:// www.shnews.co), diakses tanggal 5 Agustus 2013.

Graa, A., Dani, E. M., \& Bensaid, M., (2014). The Impact of Environmental Factors on Impulse Buying Behavior using the Mehrabian and Russel's Framwark. Leonardo Journal of Sciences, pp. 101-114.

Hair, J. F., Rolph, E., Anderson, R. L., Tatham \& William, C. B., (1998). Multivariate Data Analysis. New Jersey: Prentice-Hall.

Halbritter, J., (2005). (online) Avalilable from: www.findarticles.com.

Han, Y. K., Morgan, G. A., Kotsiopulo, A., \& Kang, P., (1991). Impulse buying of apparel purchase clothing and textiles. Research Journal, 9(3), pp. 15-21. Available from: http://dx.doi.org/10.1177/0887302x9100900 303

Harmancioglu, N., Finney, R. Z., \& Joseph, M., (2009). Impulse purchases of new products: an empirical analysis. Journal of product and Brand management, 18(10), pp. 27-37.

Hausman, A. A., (2000). Multi-method investigation of consumer motivations in impulse buying behavior". Journal Consumer Marketing, 17(5), pp. 403-419. 
Hawkin, D. I., Roger, I. J., Coney, K. A., \& Mookerjee, A., (2007). Consumer Behavior. NewDelhi: McGraw Hill.

Hoyer \& Macinner., (1999). Consumer Behavior. New York: Houghton Mifflin.

Johnes, M. A., Reynolds, K. E., Weun, I. S., \& Beatty, S. E., (2003). The Product Specific Nature Of the Impulse Buying Tendency. Journal of Business research, 56(70), pp. 505-511.

Kacen, J. J., \& Lee , J. A., (2002). The Influence of Culture on Consumer Inpulsive Buying Behavior. Journal Psychology, 12(2), pp. 163-176.

Kaur, P., \& Singh, R., (2007). Uncovering Retail Shopping Motives of India Youth. Young Consumer, 8(2), pp. 128-138.

Kotler, P., \& Keller, K. L., (2006). Marketing Management $12^{\text {th }}$ Edition. New Jersey: Prentice-Hall.

Lafferty, B. A., \& Goldsmith, R. E., (2002). Consumer response to websites and their influence on advertising effectiveness (internet research). Journal of Electronic Networking Application and Policy, 12(4), pp. 318-328.

Levy \& Weitz., (2004). Retailing Manajemen $7^{\text {th }}$ Edition. New York: McGraw-Hill

Liang, Y. P., Liang, J. L., \& Duan, Y. S., (2008). Relationship between consumer information exposure, product knowledge, and impulse purchasing behavior: An empirical ans. Intalysiernational Journal of Management, 25, pp. 418-430.

Luo, X., 2005. How does shopping with others influence impulse purhasing. Journal of Consumer Psychology, 15(4), pp. 288-294.

Mathai, S. T., \& Haridas, R., (2014). Personality its impact on impulse buying behaviour among the retail customers in Kochin city. Journal of Business and Management, 16(4), pp. 48-55.

Mattila, A. S., \& Wirtz, J., 2008. The Role Of Store Environmental Stimulation and Social Factors on Impulse Purchasing. Journal of Servise marketing, 22(7), pp. 562-567.

Michael, J. E., William, J. S., \& Pandit, A., 2010. Marketing. New Delhi: Tata Mc Graw Hill
Muruganantham, G., \& Bhakat, R. S., (2013). A Review of Impulse Buying Behavior. International journal of Marketing Studies, 5(3), pp. 1918-720.

Nielsen, A. C., (2007). Ritel di Indonesia. Media Research dan Retail Asia Magazine.

Park, E. J., Kim, E. Y., \& Forney, J. C., (2006). A Structural Model of Fashion-oriented Impulse Buying Behavior. Journal of Fashion Marketing and Mangement, 10(4), pp. 433-446.

Ruswanti, E., (2013). Cherry Pick, Shopping Satisfaction and Market Maven. Journal Economics Business and Accountancy Ventura, 16, pp. 289-308.

Ruswanti, E., (2014). Analysis of Materialism, Fashion Clothing and Recreational Shoppers' Identity. Jurnal Economics Business and Accountancy Ventura, 17(3).

Rook, D. W., (1987). The Buying Impulse. Journal of Consumer Research, 14, pp. 189199.

Rook, D. W., \& Fisher, R. J., (1995). Normative influences on impulse buying behavior. The Journal of consumer Research, 22(3), pp. 305-313.

Rook, D. W., \& Gardner, M. P., (1993). In the Mood: Impulse Buying's Affective Antesedents. Research in Consumer Behavior, 6(7), 1-28.

Rook, D. W., \& Hoch, S., (1985). Consuming Impulses. Advancesin Consumer Research, 7(1), pp. 23-27.

Shiffman, L., \& Kanuk, L., (2010). Consumer Behavior. New Delhi: Prentice Hall

Shapiro, J. M., (1992). Impulse Buying: a New Framework Developments in Marketing Science. Journal of Business Research, 15, pp. 76-80.

Sharma, P., Siv Akumaran, B., \& Marshall, R., (2010). Impulse Buying and Variety Seeking: A Trait-correlates Persepective. Journal of Business Research, 63, pp. 276283.

Shen, K. N., \& khalifa, M., (2012). System Design Effects on Line Impulse buying. Internet Research, 22(4), pp 396-425.

Sneath, J. Z., Lacey, R., \& Kennett, H. P. A., (2009). Coping with a Natural Disaster: Losses, Emotions, impulsive, and 
Compulsive buying. Marketing Letters, 20(10), pp. 45-60.

Stern, H. (1962). The significance of impulse buying today. Journal of Marketing, 26, pp. 59-63.

Verplanken, B., \& Herbadi, A., (2001). Individual differences in impulse buying tendency: Feeling and no thinking. Europan Journal of personality, 15, pp. 71-83.

Verplanken, B., Herbadi, A. P., \& Silveria., (2005). Consumer style and health: the role of impulse buying in unhealthy eating. Psychology and Health, 20(4), pp. 429-44.

Vohs, K. D., \& Faber, R. J., (2007). Spent Resources: Self-Regulatory Resource Avai- lability Affects Impulse Buying. Journal of Consumer Research, 33(4), pp 537-547.

$\mathrm{Xu}, \mathrm{Y}$., (2007). Impact of store environment on adult generation $\mathrm{Y}$ consumers impulse buying Journal of Shopping Center Research, 14(1), pp. 39-56.

Youn, S., \& Faber, R., (2000). "Impulse buying: its relation to personality traits and cues", Advances in Consumer Research, 27(1), pp. 179-185.

Yu, C., \& Bastin, M., (2010). Hedonic shopping value and impulse buying behavior in transitional economies: A symbiosis in the mainland China marketplace. Journal of Brand Management, 18(2), pp. 105-114. 